\title{
JUEGOS OLÍMPICOS MODERNOS VS ANTIGUOS
}

\section{ANCIENT VS. MODERN OLYMPICS}

\section{AUTORES}

Benjamín Hernández Blázquez: Universidad Complutense de Madrid benjamín.hernandez@mixmail.com

\section{CURRÍCULUM VITAE}

Catedrático de la Escuela Universitaria de Estadística de la Universidad Complutense de Madrid.

\section{RESUMEN}

Los Juegos Olímpicos Modernos que tuvieron como célula generatriz La Sorbona francesa, nacieron con espíritu romántico y versallesco, hoy conforman el acontecimiento humano que despierta mayor interés en el planeta. En poco más de un siglo se han separado de ese ideal neofundacional catalizado por los medios de comunicación y convergiendo en el profesionalismo y nacionalismo exacerbado en parangón de los Antiguos, lo que generó su abolición por el emperador hispano Teodosio.

\section{PALABRAS CLAVE}

Juegos - Olimpiadas - Deporte 


\begin{abstract}
The modern Olympic Games that took as a cell generating the Sorbonne French, born with romantic and Versailles, now make up the human event aroused great interest in the planet. In little more than a century have been separated from that ideal neofundacional catalyzed by the media and converging on professionalism and extreme nationalism in comparison of the Ancients, which generated its abolition by the Emperor Theodosius Hispanic.
\end{abstract}

\title{
KEY WORDS
}

Games - Olympics - Sports

Los Juegos Olímpicos Modernos que tuvieron como célula generatriz La Sorbona francesa, nacieron con espíritu romántico y versallesco, hoy conforman el acontecimiento humano que despierta mayor interés en el planeta. En poco más de un siglo se han separado de ese ideal neofundacional catalizado por los medios de comunicación y convergiendo en el profesionalismo y nacionalismo exacerbado en parangón de los Antiguos, lo que generó su abolición por el emperador hispano Teodosio.

La historia de los Juegos correlacionada con la sociedad actual, cual carrera de relevos en sus diferentes etapas civilizadoras, tiende a repetirse en lo concerniente al nacionalismo, profesionalismo y la violencia extinguiendo las ideas puras y filantrópicas originales. 
El culto a la competición lúdica es tan antiguo como noble, al menos teóricamente. Pero los antiguos griegos pronto asimilaron que los Juegos eran un achaque adecuado para la confluencia y ensamblaje de las tribus de las montañas. Los romanos sofisticaron la pugna en los "ludi circensis", su artículo de exportación el Derecho y sus manifestaciones llegaron a cobijar más de cien mil espectadores en los macrocircos. En los anfiteatros, similares a los modernos estadios, se reunían hasta 50.000 personas ejerciendo como actores los más selectos atletas púgiles y aurigas del imperio, a la vez que servían de escaparates sociales a los "turistas" de las "províncere".

Si estas cifras las relativizamos con los espectadores de cualquier evento deportivo actual, el aficionado se preguntará si son muchos o pocos; la ponderación correspondiente se encuentra en los millones de aficionados al sillón televisivo, paralelo a la cultura del ocio romano, que: "se tumbaban frente a las lujosas mesas para criticar la sociedad, el Estadio o el circo, o en las selectivas termas disfrutando de una vida sin esfuerzo".

Pero permutando las valoraciones, casi todo permanece visto desde una perspectiva histórica. En los deportes individuales, de enfrentamiento, combinados o de asociación siguen latentes el nacionalismo y la violencia como metodología del ganador, turbios laureles que emergen entre las oscuras raíces del tiempo, y que como la guerra: "no fueron inventados por el hombre sino por los dioses".

Lejos de los boicots pretéritos y la aplicación fundamentalista de la Carta caso de Cuba; en Sidney hemos asistido a los Juegos más grandes de la historia y los de mayor presupuesto "a la vez que han concurrido más países que Estados tiene la 
ONU", y que han competido bajo una bandera, es decir, bajo el signo de una clasificación política. Deportistas de élite, han ido los selectos de cada país, pero algunos de los excluidos son mejores que los primeros de otros países, los trials de USA, y, aunque se hace un control de calidad individual, subyace cierta injusticia, es decir, se subordina la excelencia deportiva al interés político de las pruebas.

Las naciones y asociaciones deportivas ya existían en tiempos olímpicos antiguos y lanzaban aparentes cruzadas auspiciadas desde vértices sociales distintos e impregnadas de lenguaje bélico; tal vez porque el deporte de alta competición, y desde sus ancestros, ha "vendido" la idea de pertenencia a una nación o a un club y no al deporte en sí. Escasos cambios ha tenido el concepto de violencia que se sitúa en la coacción impositiva que obliga a realizar algo contra voluntad.

Según las leyendas, los mismos Juegos, lejos de la imagen idealizadora por los pacíficos de Olimpia, fueron fundados por Penélope a través de un acto de engaño y violencia, y aunque el mito es sólo eso, mito, dice mucho que a los griegos no les importaba demasiado tener por inventor de los Juegos a un ventajista, a la postre, se dirían: "era un ganador". 